\title{
Risk assessment of FLT3 and PAX5 variants in B-acute lymphoblastic leukemia: a case - control study in a Pakistani cohort
}

\author{
Ammara Khalid ${ }^{\text {Corresp., } 1}{ }^{,}$, Sara Aslam ${ }^{1}$, Mehboob Ahmed ${ }^{1}$, Shahida Hasnain ${ }^{1}$, Aimen Aslam ${ }^{2}$ \\ 1 Department of Microbiology \& Molecular Genetics, University of the Punjab, Lahore, Pakistan \\ 2 Department of statistics and actuarial science, University of the Punjab, Lahore, Pakistan \\ Corresponding Author: Ammara Khalid \\ Email address: amara.mmg@pu.edu.pk
}

AIMS: B-cell acute lymphoblastic leukemia (B-ALL) is amongst most prevalent cancers of children in Pakistan. Genetic variations in FLT3 are associated with auto-phosphorylation of kinase domain that leads to increased proliferation of blast cells. Paired box family of transcription factor (PAX5) plays a critical role in commitment and differentiation of B-cells. Variations in PAX5 are associated with the risk of B-ALL. We aimed to analyze the association of FLT3 and PAX5 polymorphisms with B cell leukemia in Pakistani cohort. METHODS: We collected 155 B-ALL subject and 155 control blood samples. For analysis, genotyping was done by tetra ARMS-PCR. SPSS was used to check the association of demographic factors of SNPs present in the population with the risk of B-ALL. RESULTS: Risk allele frequency A at locus 13q12.2 (rs35958982, FLT3) was conspicuous and showed positive association $(\mathrm{OR}=2.30, \mathrm{Cl}=1.20-4.50, \mathrm{P}=0.005)$ but genotype frequency $(\mathrm{OR}=3.67, \mathrm{Cl}=0.75-18.10, \mathrm{P}=0.088)$ failed to show any association with the disease. At locus 9p13.2 (rs3780135, PAX5), the risk allele frequency was significantly more in B-ALL subjects than ancestral allele frequency $(\mathrm{OR}=2.17, \mathrm{Cl}=1.37-3.43, \mathrm{P}=0.000)$. Genotype frequency analysis of rs3780135 polymorphism exhibited the protective effect $(O R=0.55$, $\mathrm{Cl}=0.72-1.83, \mathrm{P}=0.029$ ). At locus $13 q 12.2$ ( $\mathrm{rs} 12430881, F L T 3$ ), the minor allele frequency $\mathrm{G}(\mathrm{OR}=1.15, \mathrm{Cl}=1.37-3.43, \mathrm{P}=0.043)$ and genotype frequency $(\mathrm{OR}=2.52, \mathrm{P}=0.006)$ reached significance as showed $p<0.05$. CONCLUSION: In present study, a strong risk of B-cell acute lymphoblastic leukemia was associated with rs35958982 and rs12430881 polymorphisms. However, rs3780135 polymorphism showed the protective effect. Additionally, other demographic factors like family history, smoking and consanguinity were also found to be important in risk assessment. We anticipate that the information from genetic variations in this study can aid in therapeutic approach in the future. 
1 Risk assessment of FLT3 and PAX5 variants in B-acute lymphoblastic 2 leukeima: a case-control study in a Pakistani cohort

3 Ammara Khalid ${ }^{1}$, Sara Aslam², Dr. Mehboob Ahmed ${ }^{3}$, Dr. Shahida Hasnain ${ }^{4}$, Aimen Aslam ${ }^{5}$

$4{ }^{1}$ Department of Microbiology \& Molecular Genetics, University of the Punjab, Lahore, Pakistan.

5 2Department of Microbiology \& Molecular Genetics, University of the Punjab, Lahore, Pakistan.

$6{ }^{3}$ Department of Microbiology \& Molecular Genetics, University of the Punjab, Lahore, Pakistan.

$7 \quad{ }^{4}$ Department of Microbiology \& Molecular Genetics, University of the Punjab, Lahore, Pakistan.

$8{ }^{5}$ Department of statistics and actuarial science, University of the Punjab, Lahore, Pakistan.

9 Corresponding Author:

10 Ammara Khalid ${ }^{1}$

11 Department of Microbiology \& Molecular Genetics, University of the Punjab, Lahore, Pakistan.

12 Email address: amara.mmg@pu.edu.pk

\section{Abstract}

14 AIMS: B-cell acute lymphoblastic leukemia (B-ALL) is amongst most prevalent cancers of children in Pakistan. Genetic variations in FLT3 are associated with auto-phosphorylation of kinase domain that leads to increased proliferation of blast cells. Paired box family of transcription factor $(P A X 5)$ plays a critical role in commitment and differentiation of B-cells. Variations in $P A X 5$ are associated with the risk of B-ALL. We aimed to analyze the association of FLT3 and PAX5 polymorphisms with B cell leukemia in Pakistani cohort. METHODS: We collected 155 B-ALL subject and 155 control blood samples. For analysis, genotyping was done by tetra ARMS-PCR. SPSS was used to check the association of demographic factors of SNPs present in the population with the risk of B-ALL.

RESULTS: Risk allele frequency A at locus 13q12.2 (rs35958982, FLT3) was conspicuous and showed positive association $(\mathrm{OR}=2.30, \mathrm{CI}=1.20-4.50, \mathrm{P}=0.005)$ but genotype frequency $(\mathrm{OR}=3.67, \mathrm{CI}=0.75-18.10, \mathrm{P}=0.088)$ failed to show any association with the disease. At locus 9p13.2 (rs3780135, PAX5), the risk allele frequency was significantly more in B-ALL subjects than ancestral allele frequency $(\mathrm{OR}=2.17, \mathrm{CI}=1.37-3.43, \mathrm{P}=0.000)$. Genotype frequency analysis of rs3780135 polymorphism exhibited the protective effect $(\mathrm{OR}=0.55, \mathrm{CI}=0.72-1.83, \mathrm{P}=0.029)$. At locus 13q12.2 (rs12430881, FLT3), the minor allele frequency G (OR=1.15, CI=1.37-3.43, $\mathrm{P}=0.043)$ and genotype frequency $(\mathrm{OR}=2.52, \mathrm{P}=0.006)$ reached significance as showed $\mathrm{p}<0.05$. 
31 CONCLUSION: In present study, a strong risk of B-cell acute lymphoblastic leukemia was 32 associated with rs35958982 and rs12430881 polymorphisms. However, rs3780135 33 polymorphism showed the protective effect. Additionally, other demographic factors like family 34 history, smoking and consanguinity were also found to be important in risk assessment. We 35 anticipate that the information from genetic variations in this study can aid in therapeutic 36 approach in the future.

\section{Introduction}

38 According to the Punjab cancer registry report, acute lymphoblastic leukemia (ALL) is a 39 predominant malignancy of children and it makes up most prevalent cancer in Punjab, Pakistan, 40 The worldwide incidence rate is $1-4.75$ per 100,000 people. In Pakistan ALL contributes to $17.9 \%$ among all cancers. It is characterized by mutation in blast cells in hematopoietic stem cells, spleen, neurons, gonads, lymph nodes, and hepatic cells (Portell et al., 2013). Although, BALL is very common in children but it may also occur in adult populace (Forero et al., 2013). Several demographic parameters like gender, age, family history and biological factors also play an important role in the prevalence of disease. Other factors like exposure to UV, radiations, lifestyle may also act as risk factors (Levine et al., 2016; Acharya et al., 2018). Mutation in certain genes involved in different processes like apoptosis, proliferation and differentiation of B-cells may also cause B-ALL. These genetic alterations largely affect the prediction and therapeutic approach used for medication and therapy of ALL (Tasian and Hunger, 2017). FMS-like tyrosine kinase (FLT3) belongs to class III receptor tyrosine kinase (RTK) family. Structurally, FLT3 consist of an extracellular domain at the amino terminus. This domain comprises of immunoglobulin-like transmembrane region and intracellular juxta-membrane domain (JMD). At carboxyl terminus, there are two kinase domains, separated by a kinase insert region (Gilliland and Griffin, 2002). FLT3 is expressed in normal human bone marrow especially in CD34+ hematopoietic stem, brain (Çakmak-Görür et al., 2019) and gonads (Matthews et al., 1991; Small et al., 1994) and encodes 1000 amino acid protein in humans. In the hematopoietic tissues, Binding of FL with its receptor causes auto-phosphorylation of tyrosine residues present in the kinase domain and stimulates growth of progenitor cells in the marrow and blood (Marhäll et al., 2018). This results in downstream activation of signaling pathways that are involved in regulation of cell cycle or apoptosis, including (PI3K), caspase-9 and Ras/Raf pathways and 
61 causes multiplied proliferation of cells, reduced cell apoptosis, and inhibition of B-cell 62 differentiation (Zhang and Broxmeyer, 2000).

63 In hematologic malignancy, $70 \%$ to $100 \%$ increased expression of FLT3 in acute myeloid 64 leukemia (AML) and acute lymphoblastic leukemia (ALL) is reported previously (Brown et al., 65 2005; Griffith et al., 2016). Rosnet and colleagues reported 3 of 5 ALL subjects with increased 66 expression of FLT3 in leukemia blasts (Rosnet et al., 1996). Another study showed that up 67 regulation of FLT3 gene is a potential risk factor of leukemia (Cheng et al., 2018).

68 B-cell-specific activator protein $(P A X 5)$ encodes transcription factors that are the member of a 69 paired box domain. $P A X 5$ plays imperative role in the commitment of B-cell lineage from blast 70 cells as it controls the differentiation of a pro-B cell to pre-B cells (Fuxa and Skok, 2007; Lang et al., 2007). In pre-pro-B cells the immunoglobin gene rearrangement starts and matures into proB cells. Expression of PAX5 gene initiates from pro-B stage and terminates at pre-B stage. In late B-lymphoposis, PAX5 maintains the function of mature B-cells (Shahjahani et al., 2015). In B-cell malignancies, $P A X 5$ act as an oncogene. Down-regulation of $P A X 5$ halts B-cells and 75 reverts B-cell precursors (BCPs) to progenitors (pro B-cell stage) (Schebesta et al., 2007; Carotta 76 and Nutt, 2008). Conversely, uncontrolled proliferation of the B-cells leads to the abnormal expression of $P A X 5$ in precursor cells and inhibit T-cell proliferation (Souabni et al., 2007). It is reported that in childhood acute lymphoblastic leukemia (ALL), translocations and mutation in 79 PAX5 are more prevalent (Bousquet et al., 2007; Nebral et al., 2009; Santoro et al., 2009; Iacobucci and Mullighan, 2017). Alternative splicing of $P A X 5$ in exon 7 to exon 9 results into five isoforms. These isoforms are more expressed in primary B-cell lymphoma tissues and cancerous cell lines (Zwollo et al., 1997; Arseneau et al., 2009).

Previous studies showed that the presence of single nucleotide polymorphisms (SNPs) in genome maybe risk causing or protective for the disease and it may also alters the pharmacokinetic and pharmacodynamics properties of drugs (Kumanayake, 2013; Pui, 2015; Tasian and Hunger, 2017). We selected two non-synonomous SNPs including 13q12.2 (rs35958982, FLT3), 557 (Val > Ile) at position Chr13:28034336 (GRCh38.p12) and 9p13.2 (rs3780135, PAX5), 293 (Thr >Ile) at position Chr9:36840626 (GRCh38.p12). A synonomous SNP 13q12.2 (rs12430881, FLT3), $(A>G)$ at position Chr13:28020665 (GRCh38.p12) was also selected. The change in amino acid sequence due to non-synonomous SNP alters the protein structure implicating its expression and function. Current study is designed to evaluate the role of FLT3 and PAX5 genes in B-cell 
92 lymphoblastic leukemia. For this purpose, a case control analysis was conducted to evaluate the 93 polymorphic association of rs35958982, rs3780135 and rs12430881 with B-cell acute 94 lymphoblastic leukemia (B-ALL) incidence.

\section{Materials \& Methods}

\section{Study subjects}

97 The present study was conducted at the University of Punjab, Pakistan and granted ethical 98 approval to carry out the study within its facilities (Ethical Application Ref: sbs/222/18). Blood samples were collected during the period of January 2017 to February 2017 from Children's Hospital, Lahore, Pakistan. Study population comprised of 155 cases and 155 controls younger than 15 years of age. The diagnostic criteria for B-ALL cases include B-cell positive markers (CD19, CD10, CD22, and CD20) confirmed by flow cytometry analysis. Cases with relapsed

103

104

105

106

107

108

109

110

111

112

113

114

115

116

117

118

119

120

121 and newly diagnosed B-ALL were also included. All 310 subjects recruited were consented to participate in this study after filling the questionnaire. The subjects with any other type of leukemia, blood infectious disease, and B-ALL subjects older than 15 years of age were excluded from the study. Family history with cancer, parental consanguinity (first and second degree relatives) and smoking status (>100 cigarettes in lifetime) were gathered by questionnaire interviewed.

\section{Genotyping:}

Venous blood samples of cases and controls were collected in EDTA vials. DNA extraction was done using Sam brook 2001 organic protocol. The genes and SNPs associated with B-ALL were screened using DisGeNET platform (Queralt-Rosinach et al., 2016) and were verified by dbSNP database (Sherry et al., 2001). Presence of the selected SNPs in Pakistani population was confirmed by Ensembl genome browser (Frankish et al., 2017). In order to identify the SNPs, tetra arm primers were designed using Primer1 software (Ye et al., 2001) as shown in table 1. Tetra arms PCR was done using advanced primus 96 (PeqLab) thermal cycler (table 2). PCR products were further analyzed by gel electrophoresis (fig. 1, 2, and 3).

\section{Statistical analysis:}

Statistical studies were performed using IBM SPSS 23. Chi-square test was conducted to compare categorical data. Allele and genotype association between SNPs and B-ALL were calculated by computing odds ratio (OR) and 95\% confidence interval (CI). The Bonferroni 
122 corrections were applied for all multiple tests. A logistic regression model was used to adjust

123 different B-ALL risk factors. The probability level accepted for significance was $P<0.05$.

\section{Results}

125 Family history of cancer and parental consanguinity showed significant association with B-ALL

126 while, there was no association with the smoker parents. Subjects with a family history of any 127 type of cancer showed a high risk of having $B-A L L(O R=15.42, \mathrm{P}=0.000)$. Previous studies 128 showed smoking as a risk factor for cancer but our cohort displayed a contradictory results as no 129 significant association was found in $\mathrm{B}-\mathrm{ALL}$ subjects $(\mathrm{OR}=0.85, \mathrm{P}=0.580)$. In the present study, 130 more B-ALL subjects were product of parental consanguinity and showed highly significant 131 association with the risk of $\mathrm{B}-\mathrm{ALL}(\mathrm{OR}=1.87, \mathrm{P}=0.050)$ (Table: 3$)$.

132 Our data showed that none of the subjects and their parents was exposed to radiations. 133 Furthermore, eighteen patients had liver hepatomegaly sized $11.7 \pm 3.3 \mathrm{~mm}$, nine cases had 134 nephropathy of right kidney $9.47 \pm 2.9 \mathrm{~mm}$ and left kidney $10.01 \pm 2.3 \mathrm{~mm}$. Symptoms like night 135 sweating, dizziness, abdominal pain, vomiting, bruises, pallor, enlarged lymph nodes, cough 136 with blood, loose stools, jaundice, pedal edema, pain, dehydration, hepatosplenomegaly, atypical 137 blast cells mild abdominal ascites, low leukocytes and thrombocytopenia were also recorded.

138 In our cohort, rs35958982 encoding isloleucine form of codon frequency in subjects was $13.4 \%$ 139 and $5.6 \%$ in controls. Moreover, statistical analysis showed positive association of allele 140 frequency $(\mathrm{OR}=2.30, \mathrm{CI}=1.20-4.50, \mathrm{P}=0.005)$ and no association of genotype frequency $141(\mathrm{OR}=3.67, \mathrm{CI}=0.75-18.10, \mathrm{P}=0.088)$ with the disease. Another polymorphism rs3780135, a 142 minor allele frequency in subjects was $47.1 \%$ and $32.58 \%$ in controls showing positive 143 association with $\mathrm{B}-\mathrm{ALL}(\mathrm{OR}=2.17, \mathrm{CI}=1.37-3.43, \mathrm{P}=0.000)$. The genotype frequency showed 144 protective effect with $\mathrm{B}-\mathrm{ALL}(\mathrm{OR}=0.55, \mathrm{CI}=0.72-1.83, \mathrm{P}=0.029)$. The $\mathrm{SNP}$ rs12430881 allele 145 frequency $(\mathrm{OR}=1.15, \mathrm{CI}=1.37-3.43, \mathrm{P}=0.043)$ and genotype frequency $(\mathrm{OR}=2.52, \mathrm{CI}=1.28-4.95$, $146 \mathrm{P}=0.006$ ) showed strong association with the disease as shown in table: 4. After applying 147 Bonferroni correction, SNPs rs35958982, rs3780135 and rs12430881 remained statistically 148 significant and showed P-value $0.030,0.010$ and 0.002 respectively.

149 Multivariate regression analysis was performed after adjusting the baseline for conventional B150 ALL risk factors such as family history, smoking and parental consanguinity. As shown in table 151 4, the multivariate analysis indicated that outcome of heterozygous genotype GA in SNPs 152 rs35958982, rs3780135 and rs12430881 had significant association with B-ALL and showed 
153 odds ratio $(\mathrm{OR}=1.13, \mathrm{CI}=0.41-3.08),(\mathrm{OR}=1.19, \mathrm{CI}=0.52-2.73)$ and $(\mathrm{OR}=1.09, \mathrm{CI}=0.48-2.69)$

154 respectively. Additionally, risk genotypes in SNPs rs35958982 (AA) and rs12430881 (GG)

155 showed positive association with disease having an odds ratio $(\mathrm{OD}=1.30, \mathrm{CI}=0.37-5.08)$ and

$156(\mathrm{OD}=1.03, \mathrm{CI}=0.50-2.68)$ respectively. However, the risk genotype (AA) of SNP rs3780135 157 displayed no association with B-ALL after adjusting for environmental factors. Stratification 158 analysis of environmental factors showed smoking as major risk factor in both heterozygous and 159 risk genotype of SNP rs3780135 and rs12430881 whereas, parental consanguinity act as risk 160 factor only in heterozygous genotype of SNP rs3780135 as shown in table 5.

\section{Discussion}

162 According to the previous studies, association of first and second degree family history of cancer 163 signifies genetic and environmental risk factor for causing acute lymphoblastic leukemia. Our 164 study also showed positive association of family history with B-ALL ( $\mathrm{OR}=15.42, \mathrm{P}=0.000$ ). 165 Earlier, parental smoking has also been associated with the prevalence of ALL but our study 166 showed contrary results ( $\mathrm{OR}=0.85, \mathrm{P}=0.580)$ (Belson et al., 2007). Parental consanguinity is still 167 practiced in Pakistan, which results in minor allele pool and contributes to the occurrence of 168 disease. Our results are in accordance with (Steinberg and Steinfeld, 1960; Urtishak et al., 2016) 169 which states that familial occurrence of leukemia exists $(\mathrm{OR}=1.87, \mathrm{P}=0.050)$. Some studies 170 found a correlation between parental exposure to radiation before conception, that may be due to 171 their working environment (Shu et al., 2002). In our analysis, nor of patients neither of parents 172 was ever exposed to radiations. Hepatomegaly and nephropathy are often seen in B-ALL 173 subjects having chemotherapy. Malfunctioned leucocytes in the liver and kidney leads to 174 enlargement of these organs (Rasool et al., 2015). Another study suggests that hepatomegaly and 175 nephropathy may be the consequence of chemotherapeutic toxicity (Giamanco et al., 2016).

176 It is well established fact that cancer risk is influenced by numerous genetic variants having any 177 risk or protective effect. The degree of penetrance of a certain genotype in the population and 178 environmental factors is a major cause of cancer (Fletcher and Houlston, 2010). The information given by allelic and genotypic data of single nucleotide polymorphism in a population propose 180 the possible genetic markers for cancer risk and predict possible targeted therapies (Griffith et 181 al., 2016; $\mathrm{Wu}$ and $\mathrm{Li}, 2018)$.

182 In this study, SNP rs35958982 is a germline polymorphism present in transmembrane region of 183 FLT3 gene. It is a non-synonymous variant which leads to the change in structure of the protein. 
184 High throughput DNA sequence analysis has been done to check the frequency of rs35958982 185 with leukemiogenesis in drivers and passengers which showed no association with AML 186 (Fröhling et al., 2007). Present study in contrast displayed the association of SNP rs35958982 187 with the disease $(\mathrm{OR}=2.30, \mathrm{CI}=1.20-4.50, \mathrm{P}=0.005)$. Detailed analysis of genotype frequency in 188 the population showed no association with $\mathrm{B}-\mathrm{ALL}(\mathrm{OR}=3.67, \mathrm{CI}=0.75-18.10, \mathrm{P}=0.088)$. This 189 might be due to the fact that SNP rs35958982 is rare in acute lymphoblastic leukemia with low 190 penetrance. Current study also depicts that individuals with risk allele A at locus $13 \mathrm{q} 12.2$ 191 (rs12430881, FLT3) $(\mathrm{OR}=1.15, \mathrm{CI}=1.37-3.43, \mathrm{P}=0.0426)$ and genotype $\mathrm{GG}$ were more prone to 192 B-ALL $(\mathrm{OR}=2.52, \mathrm{CI}=1.28-4.95, \mathrm{P}=0.006)$. It has been found that disruption of FLT3 gene due 193 to the presence of mutation or SNP leads to deficiency of B-lymphoid progenitors suggesting its 194 critical role in survival and proliferation of blast cells (Zriwil et al., 2018).

195 Bodian et al., studied allele frequency of paired box domain ( $P A X 5$ ) polymorphism rs 3780135 196 in different populations i.e. African 34\%, African European 49\%, Central Asian 85\%, East Asian 197 94\%, European 95\% and Hispanic 88\% (Bodian et al., 2014). Pakistan lies in South East Asia 198 having frequency of rs3780135 (47.1\%) which is lower than previously reported in East Asian 199 population. Firtina et al., found polymorphism rs3780135 in B-ALL subjects with increased 200 mRNA expression of PAX5 suggesting the possible role of SNP with increased proliferation of 201 blast cells (Firtina et al., 2012). In Pakistani population, minor allele frequency was significantly 202 identified in $\mathrm{B}-\mathrm{ALL}$ subjects $(\mathrm{OR}=2.17, \mathrm{CI}=1.37-3.43, \mathrm{P}=0.000)$. Heterozygous genotype GA $203(38.7 \%)$ was more frequently identified in our cohort than homozygous risk genotype AA 204 (27.74\%) which manifested significant difference in frequency $(\mathrm{CI}=0.72-1.83, \mathrm{P}=0.029)$ and also 205 showed protective effect $(\mathrm{OR}=0.55)$. PAX5 is involved in repression of T-cells, activation of B206 cell proliferation from blast cell therefore, presence of any variant in this gene affects its 207 pathway which may leads to increased expression of $P A X 5$ and results into B-ALL (Firtina et 208 al., 2012).

\section{Conclusions}

210 The findings of the present study significantly demonstrate that SNPs rs35958982 and 211 rs12430881 correlates with the increase risk of B-ALL however, SNP rs3780135 has protective 212 effect. The environmental risk factors of B-ALL including family history, parental consanguinity 213 and smoking are found to have imperative role in progression of disease. Although the data is 214 balanced but not robust and a small cohort of subjects limits the conclusion of manuscript. To 
215 eliminate limitation and validate the results of present study, larger prospective studies need to 216 be conducted in the same ethnic group. Furthermore various other demographic and 217 environmental factors should also be considered and appraised for their association with B-ALL.

\section{Acknowledgements}

219 Authors would like to acknowledge The Children's Hospital and Institute of Child Health, 220 Lahore, Pakistan for their assistance and support during blood sample collection.

\section{References}

222 Acharya, U. H., Halpern, A. B., Wu, Q., Voutsinas, J. M., Walter, R. B., Yun, S., Kanaan, M.

223

224

225

226

227

228

229

230

231

232

233

234

235

236

237

238

239

240

241

242

243

244 and Estey, E. H. 2018. Impact of region of diagnosis, ethnicity, age, and gender on survival in acute myeloid leukemia (AML). Journal of drug assessment, 7:51-53.

Arseneau, J. R., Laflamme, M., Lewis, S. M., Maïcas, E. and Ouellette, R. J. 2009. Multiple isoforms of PAX5 are expressed in both lymphomas and normal B-cells. British journal of haematology, 147:328-338.

Belson, M., Kingsley, B. and Holmes, A. 2007. Risk factors for acute leukemia in children: a review. Environmental health perspectives, 115:138.

Bodian, D. L., McCutcheon, J. N., Kothiyal, P., Huddleston, K. C., Iyer, R. K., Vockley, J. G. and Niederhuber, J. E. 2014. Germline variation in cancer-susceptibility genes in a healthy, ancestrally diverse cohort: implications for individual genome sequencing. PloS one, 9:e94554.

Bousquet, M., Broccardo, C., Quelen, C., Meggetto, F., Kuhlein, E., Delsol, G., Dastugue, N. and Brousset, P. 2007. A novel PAX5-ELN fusion protein identified in B-cell acute lymphoblastic leukemia acts as a dominant negative on wild-type PAX5. Blood, 109:3417-3423.

Brown, P., Levis, M., Shurtleff, S., Campana, D., Downing, J. and Small, D. 2005. FLT3 inhibition selectively kills childhood acute lymphoblastic leukemia cells with high levels of FLT3 expression. Blood, 105:812-820.

Çakmak-Görür, N., Radke, J., Rhein, S., Schumann, E., Willimsky, G., Heppner, F. L., Blankenstein, T. and Pezzutto, A. 2019. Intracellular expression of FLT3 in Purkinje cells: implications for adoptive T-cell therapies. Leukemia:1.

Carotta, S. and Nutt, S. L. 2008. Losing B cell identity. Bioessays, 30:203-207. 
245 Cheng, J., Qu, L., Wang, J., Cheng, L. and Wang, Y. 2018. High expression of FLT3 is a risk 246 factor in leukemia. Molecular medicine reports, 17:2885-2892.

247 Firtina, S., Sayitoglu, M., Hatirnaz, O., Erbilgin, Y., Oztunc, C., Cinar, S., Yildiz, I., Celkan, T., 248 Anak, S. and Unuvar, A. 2012. Evaluation of PAX5 gene in the early stages of leukemic

251 252 253 254 255 256 257 258 259 260 261 262 263 264 265 266 267 268 269

270 271 272 273 274 B cells in the childhood B cell acute lymphoblastic leukemia. Leukemia research, 36:8792.

Fletcher, O. and Houlston, R. S. 2010. Architecture of inherited susceptibility to common cancer. Nature Reviews Cancer, 10:353.

Forero, R. M., Hernández, M. and Rivas, J. M. H. 2013. Genetics of Acute Lymphoblastic Leukemia. In: Guenova, M. and Balatzenko, G. [Eds.] Leukemia. InTech, Rijeka, pp. Ch. 01.

Frankish, A., Vullo, A., Zadissa, A., Yates, A., Thormann, A., Parker, A., Gall, A., Moore, B., Walts, B., Aken, B. L., Cummins, C., Girón, C. G., Ong, C. K., Sheppard, D., Staines, D. M., Murphy, D. N., Zerbino, D. R., Ogeh, D., Perry, E., Haskell, E., Martin, F. J., Cunningham, F., Riat, H. S., Schuilenburg, H., Sparrow, H., Lavidas, I., Loveland, J. E., To, J. K., Mudge, J., Bhai, J., Taylor, K., Billis, K., Gil, L., Haggerty, L., Gordon, L., Amode, M R., Ruffier, M., Patricio, M., Laird, M. R., Muffato, M., Nuhn, M., Kostadima, M., Langridge, N., Izuogu, O. G., Achuthan, P., Hunt, S. E., Janacek, S. H., Trevanion, S. J., Hourlier, T., Juettemann, T., Maurel, T., Newman, V., Akanni, W., McLaren, W., Liu, Z., Barrell, D. and Flicek, P. 2017. Ensembl 2018. Nucleic Acids Research, 46:D754-D761.

Fröhling, S., Scholl, C., Levine, R. L., Loriaux, M., Boggon, T. J., Bernard, O. A., Berger, R., Döhner, H., Döhner, K. and Ebert, B. L. 2007. Identification of driver and passenger mutations of FLT3 by high-throughput DNA sequence analysis and functional assessment of candidate alleles. Cancer cell, 12:501-513.

Fuxa, M. and Skok, J. A. 2007. Transcriptional regulation in early B cell development. Current opinion in immunology, 19:129-136.

Gardner, M. J. 1991. Father's occupational exposure to radiation and the raised level of childhood leukemia near the Sellafield nuclear plant. Environmental health perspectives, 94:5. 
275 Giamanco, N. M., Cunningham, B. S., Klein, L. S., Parekh, D. S., Warwick, A. B. and Lieuw, K.

276

277

278

279

280

281

282

283

284

285

286

287

288

289

290

291

292

293

294

295

296

297

298

299

300

301

302

303

304

305 2016. Allopurinol Use During Maintenance Therapy for Acute Lymphoblastic Leukemia Avoids Mercaptopurine-related Hepatotoxicity. Journal of pediatric hematology/oncology, 38:147-151.

Gilliland, D. G. and Griffin, J. D. 2002. The roles of FLT3 in hematopoiesis and leukemia. Blood, 100:1532-1542.

Griffith, M., Griffith, O. L., Krysiak, K., Skidmore, Z. L., Christopher, M. J., Klco, J. M., Ramu, A., Lamprecht, T. L., Wagner, A. H. and Campbell, K. M. 2016. Comprehensive genomic analysis reveals FLT3 activation and a therapeutic strategy for a patient with relapsed adult B-lymphoblastic leukemia. Experimental hematology, 44:603-613.

Iacobucci, I. and Mullighan, C. G. 2017. Genetic basis of acute lymphoblastic leukemia. Journal of Clinical Oncology, 35:975.

Kumanayake, P. 2013. Genome-wide SNP discovery in associating with human diseases phenotypes. Sri Lanka Journal of Bio-Medical Informatics, 3.

Lang, D., Powell, S. K., Plummer, R. S., Young, K. P. and Ruggeri, B. A. 2007. PAX genes: roles in development, pathophysiology, and cancer. Biochemical pharmacology, 73:1-14.

Levine, P. H., Ajmera, K., O’Neill, B., Venkatesh, V., Garcia-Gonzalez, P. and Hoffman, H. J. 2016. Demographic factors related to young age at diagnosis of chronic myeloid leukemia in India. Clinical Epidemiology and Global Health, 4:188-192.

Marhäll, A., Heidel, F., Fischer, T. and Rönnstrand, L. 2018. Internal tandem duplication mutations in the tyrosine kinase domain of FLT3 display a higher oncogenic potential than the activation loop D835Y mutation. Annals of hematology, 97:773-780.

Matthews, W., Jordan, C. T., Wiegand, G. W., Pardoll, D. and Lemischka, I. R. 1991. A receptor tyrosine kinase specific to hematopoietic stem and progenitor cell-enriched populations. Cell, 65:1143-1152.

Nebral, K., Denk, D., Attarbaschi, A., König, M., Mann, G., Haas, O. A. and Strehl, S. 2009. Incidence and diversity of PAX5 fusion genes in childhood acute lymphoblastic leukemia. Leukemia, 23:134.

Portell, C. A., Wenzell, C. M. and Advani, A. S. 2013. Clinical and pharmacologic aspects of blinatumomab in the treatment of B-cell acute lymphoblastic leukemia. Clinical pharmacology: advances and applications, 5:5. 
306 Pui, C.-H. 2015. Genomic and pharmacogenetic studies of childhood acute lymphoblastic

307

308

309

310

311

312

313

314

315

316

317

318

319

320

321

322

323

324

325

326

327

328

329

330

331

332

333

334

335

336 leukemia. Frontiers of medicine, 9:1-9.

Queralt-Rosinach, N., Pinero, J., Bravo, À., Sanz, F. and Furlong, L. I. 2016. DisGeNET-RDF: harnessing the innovative power of the Semantic Web to explore the genetic basis of diseases. Bioinformatics, 32:2236-2238.

Rasool, M., Farooq, S., Malik, A., Shaukat, A., Manan, A., Asif, M., Sani, S., Qazi, M. H., Kamal, M. A. and Iqbal, Z. 2015. Assessment of circulating biochemical markers and antioxidative status in acute lymphoblastic leukemia (ALL) and acute myeloid leukemia (AML) patients. Saudi journal of biological sciences, 22:106-111.

Rosnet, O., Bühring, H., Marchetto, S., Rappold, I., Lavagna, C., Sainty, D., Arnoulet, C., Chabannon, C., Kanz, L. and Hannum, C. 1996. Human FLT3/FLK2 receptor tyrosine kinase is expressed at the surface of normal and malignant hematopoietic cells. Leukemia, 10:238-248.

Santoro, A., Bica, M. G., Dagnino, L., Agueli, C., Salemi, D., Cannella, S., Veltroni, M., Cetica, V., Giarin, E. and Fabbiano, F. 2009. Altered mRNA expression of PAX5 is a common event in acute lymphoblastic leukaemia. British journal of haematology, 146:686-689.

Schebesta, A., McManus, S., Salvagiotto, G., Delogu, A., Busslinger, G. A. and Busslinger, M. 2007. Transcription factor Pax5 activates the chromatin of key genes involved in B cell signaling, adhesion, migration, and immune function. Immunity, 27:49-63.

Shahjahani, M., Norozi, F., Ahmadzadeh, A., Shahrabi, S., Tavakoli, F., Asnafi, A. A. and Saki, N. 2015. The role of Pax5 in leukemia: diagnosis and prognosis significance. Medical Oncology, 32:360.

Sherry, S. T., Ward, M.-H., Kholodov, M., Baker, J., Phan, L., Smigielski, E. M. and Sirotkin, K. 2001. dbSNP: the NCBI database of genetic variation. Nucleic acids research, 29:308311.

Shu, X. O., Potter, J. D., Linet, M. S., Severson, R. K., Han, D., Kersey, J. H., Neglia, J. P., Trigg, M. E. and Robison, L. L. 2002. Diagnostic X-rays and ultrasound exposure and risk of childhood acute lymphoblastic leukemia by immunophenotype. Cancer Epidemiology and Prevention Biomarkers, 11:177-185.

Small, D., Levenstein, M., Kim, E., Carow, C., Amin, S., Rockwell, P., Witte, L., Burrow, C., Ratajczak, M. Z. and Gewirtz, A. M. 1994. STK-1, the human homolog of Flk-2/Flt-3, is 
337

338

339

340

341

342

343

344

345

346

347

348

349

350

351

352

353

354

355

356

357

358

359

360

361

362

363

364

365

366

selectively expressed in CD34+ human bone marrow cells and is involved in the proliferation of early progenitor/stem cells. Proceedings of the National Academy of Sciences, 91:459-463.

Souabni, A., Jochum, W. and Busslinger, M. 2007. Oncogenic role of Pax5 in the T-lymphoid lineage upon ectopic expression from the immunoglobulin heavy-chain locus. Blood, 109:281-289.

Steinberg, A. G. and Steinfeld, J. L. 1960. The genetics of acute leukemia in children. Cancer, 13:985-999.

Tasian, S. K. and Hunger, S. P. 2017. Genomic characterization of paediatric acute lymphoblastic leukaemia: an opportunity for precision medicine therapeutics. British journal of haematology, 176:867-882.

Urtishak, K. A., Robinson, B. W., Rappaport, E. F., Sarezky, M. D., Biegel, J. A., Nichols, K. E., Wilmoth, D. M., Wang, L. S., Stern, J. W. and Felix, C. A. 2016. Unique Familial MLL (KMT2A)-Rearranged Precursor B-Cell Infant Acute Lymphoblastic Leukemia in Non-twin Siblings. Pediatric blood \& cancer, 63:1175-1180.

Wu, C. and Li, W. 2018. Genomics and pharmacogenomics of pediatric acute lymphoblastic leukemia. Critical reviews in oncology/hematology.

Ye, S., Dhillon, S., Ke, X., Collins, A. R. and Day, I. N. 2001. An efficient procedure for genotyping single nucleotide polymorphisms. Nucleic acids research, 29:e88-e88.

Zhang, S. and Broxmeyer, H. E. 2000. Flt3 ligand induces tyrosine phosphorylation of gab1 and gab2 and their association with shp-2, grb2, and PI3 kinase. Biochemical and biophysical research communications, 277:195-199.

Zriwil, A., Böiers, C., Kristiansen, T. A., Wittmann, L., Yuan, J., Nerlov, C., Sitnicka, E. and Jacobsen, S. E. 2018. Direct role of FLT 3 in regulation of early lymphoid progenitors. British journal of haematology, 183:588-600.

Zwollo, P., Arrieta, H., Ede, K., Molinder, K., Desiderio, S. and Pollock, R. 1997. The Pax-5 gene is alternatively spliced during B-cell development. Journal of Biological Chemistry, 272:10160-10168.

PeerJ reviewing PDF | (2019:02:35081:2:1:NEW 23 May 2019) 
Table $\mathbf{1}$ (on next page)

Tetra-ARMS primers 


\begin{tabular}{lcc}
\hline Primer & Sequence (5'-3') & Tm \\
\hline \multirow{2}{*}{ rs35958982 } & TGTGACAAATTAGCAGGGTTAACAC & 57.3 \\
& GAAACTCCCATTTGAGATCATATTCA & 56.0 \\
& AGACAGAGACAAGCAGACATTCG & 58.4 \\
\hline \multirow{2}{*}{$\mathbf{r s 3 7 8 0 1 3 5}$} & CTCTTCCAGGCTCCCCCGAC & 59.2 \\
& GGGCGGCAGCGCTATAAGAA & 59.5 \\
& ACCCCAGCTCTAGATGGCGAAG & 56.6 \\
& ATAGGTGCCATCAGTGTTTGGTGC & 58.4 \\
\hline & GTTTGTCTCCTCTTCATTGGCA & 56.0 \\
& GCCTCAGTGTCATCTTCGAATT & 56.3 \\
& CCTTTTATCTTCACATCAGGCCT & 56.6 \\
& CTAGTAGAGATGGGGTTTTGCC & 58.4 \\
\hline
\end{tabular}


Table 2 (on next page)

PCR program for SNPS 


\begin{tabular}{cccc}
\hline PCR steps & Temperature $\left({ }^{\circ} \mathrm{C}\right)$ & Duration of steps $(\mathbf{m i n})$ & No. of cycles \\
\hline $\begin{array}{c}\text { Initial } \\
\text { duration }\end{array}$ & 92 & $5 \mathrm{~min}$ & \\
$\begin{array}{c}\text { Denaturation } \\
\text { Annealing }\end{array}$ & 94 & $30 \mathrm{sec}$ & \\
rs35958982 & $58.4^{\circ} \mathrm{C}$ & $1 \mathrm{~min}$ & $30-35$ \\
rs3780135 & $56.6^{\circ} \mathrm{C}$ & & \\
rs12430881 & $58.8 \mathrm{C}$ & $1 \mathrm{~min}$ \\
Extension & 72 & $5 \mathrm{~min}$ \\
Final & 72 & \\
extension & & & \\
\hline
\end{tabular}

1 


\section{Table 3(on next page)}

Association of demographic factors with risk of B-ALL.

Significant values are shown in $(*)$ 


\begin{tabular}{|c|c|c|c|c|c|}
\hline Parameters & $\begin{array}{c}\text { Patients } \\
(\%)\end{array}$ & $\begin{array}{c}\text { Control } \\
(\%)\end{array}$ & $\begin{array}{c}\text { Odd } \\
\text { Ratio }\end{array}$ & Chi-square & P value \\
\hline Age (mean) & 7.30 & 11.70 & & & \\
\hline A positive family history & 16.77 & 1.29 & & & \\
\hline A negative family history & 83.22 & 98.70 & 15.42 & 14.59 & $0.000 *$ \\
\hline Smoking by parent & 38.06 & 41.94 & & & \\
\hline No smoking parent & 61.93 & 58.06 & 0.85 & 0.31 & 0.580 \\
\hline Parental cousin marriage & 33.55 & 21.29 & & & \\
\hline No cousin marriage & 66.45 & 78.70 & 1.87 & 3.78 & $0.050 *$ \\
\hline Females & 56 & 72 & & & \\
\hline Males & 99 & 83 & 0.65 & 3.41 & 0.070 \\
\hline
\end{tabular}

1 


\section{Table 4(on next page)}

\section{Allele and genotype frequency}

Adjusted ORs were obtained from logistic regression model with adjustment for family history, smoking and consanguinity.

${ }^{1}$ Critical P value, ${ }^{2}$ Bonferroni corrected $\mathrm{P}$ value 
1

\begin{tabular}{|c|c|c|c|c|c|c|c|c|}
\hline Gene/SNP & $\begin{array}{c}\text { Allele/ } \\
\text { Genotype }\end{array}$ & $\begin{array}{c}\text { Controls } \\
(\%)\end{array}$ & $\begin{array}{c}\text { Cases } \\
(\%)\end{array}$ & $\begin{array}{c}\text { Crude } \\
\text { OR } \\
(95 \% \mathrm{CI})\end{array}$ & $\begin{array}{c}\text { Adjusted } \\
\text { OR } \\
(95 \% \mathrm{CI})\end{array}$ & $\chi^{2}$ & $\begin{array}{c}{ }^{1} \mathbf{P}- \\
\text { value }\end{array}$ & $\begin{array}{c}{ }^{2} \mathbf{P}- \\
\text { value }\end{array}$ \\
\hline \multirow{7}{*}{ rs35958982 } & Allele & & & & & \multirow{4}{*}{7.79} & \multirow{4}{*}{$0.005^{*}$} & \multirow{4}{*}{$0.002 *$} \\
\hline & A & 5.60 & 13.40 & 2.30 & --- & & & \\
\hline & $\mathrm{G}$ & 94.40 & 86.60 & $(1.20-4.50)$ & --- & & & \\
\hline & Genotype & & & & & & & \\
\hline & GG & 90.70 & 79.60 & & 1.00 & \multirow{3}{*}{2.90} & \multirow{3}{*}{0.088} & \multirow{3}{*}{$0.030^{*}$} \\
\hline & GA & 7.60 & 13.80 & $\begin{array}{c}3.67 \\
(0.75-18.10)\end{array}$ & $\begin{array}{c}1.13 \\
(0.41-3.08)\end{array}$ & & & \\
\hline & $\mathrm{AA}$ & 1.85 & 6.50 & & $\begin{array}{c}1.30 \\
(0.37-5.08)\end{array}$ & & & \\
\hline
\end{tabular}

Allele

\begin{tabular}{|c|c|c|c|c|c|c|c|}
\hline A & 32.58 & 47.10 & 2.17 & --- & \multirow{2}{*}{13.63} & \multirow{2}{*}{$0.000 *$} & $0000 *$ \\
\hline G & 67.42 & 52.90 & $(1.37-3.43)$ & --- & & & \\
\hline
\end{tabular}

Genotype

rs3780135

\begin{tabular}{|c|c|c|c|c|c|c|c|}
\hline GG & 52.26 & 33.55 & & 1.00 & & & \\
\hline GA & 30.32 & 38.70 & $\begin{array}{c}0.55 \\
(0.39-0.95)\end{array}$ & $\begin{array}{c}1.19 \\
(0.52-2.73)\end{array}$ & 4.72 & $0.029 *$ & $0.010^{*}$ \\
\hline AA & 17.42 & 27.74 & & $\begin{array}{c}0.97 \\
(0.26-1.42)\end{array}$ & & & \\
\hline
\end{tabular}

Allele

$\begin{array}{cccccccc}\text { G } & 22 & 29 & 1.15 & --- & 4.11 & 0.043^{*} & 0.014^{*} \\ \text { A } & 78 & 71 & (0.72-1.83) & --- & & & \end{array}$

rs12430881 Genotype

\begin{tabular}{cccccccc} 
AA & 65.16 & 61.93 & 2.52 & 1.00 & & & \\
& & & $(1.28-4.95)$ & 1.09 & 7.51 & $0.006^{*}$ & $0.002 *$ \\
GA & 25.80 & 18.06 & & $(0.48-2.69)$ & & & \\
\hline
\end{tabular}




\begin{tabular}{llcc}
\hline GG & 9.03 & 20 & 1.03 \\
$(0.50-2.68)$ \\
\hline
\end{tabular}

3

4

5

6

7

8

9

10

11

12 


\section{Table 5 (on next page)}

Stratification analysis for association between genotypes and risk of B-ALL

ORs were obtained from logistic regression model with adjustment for family history, smoking and consanguinity. 


\begin{tabular}{|c|c|c|c|}
\hline \multirow{2}{*}{ rs35958982 } & \multicolumn{3}{|c|}{ OR (95\% CI) } \\
\hline & GG & GA & $\mathbf{A A}$ \\
\hline \multicolumn{4}{|c|}{ Family history status } \\
\hline Yes & \multirow{2}{*}{1} & \multirow{2}{*}{$0.92(0.18-4.56)$} & \multirow{2}{*}{$0.50(0.06-4.15)$} \\
\hline No & & & \\
\hline \multicolumn{4}{|l|}{ Smoking status } \\
\hline Yes & \multirow{2}{*}{1} & \multirow{2}{*}{$0.30(0.08-1.09)$} & \multirow{2}{*}{$0.46(0.10-2.12)$} \\
\hline No & & & \\
\hline \multicolumn{4}{|c|}{ Consanguinity status } \\
\hline Yes & \multirow{2}{*}{1} & \multirow{2}{*}{$0.86(0.24-3.10)$} & \multirow{2}{*}{$0.94(0.20-4.37)$} \\
\hline No & & & \\
\hline rs3780135 & GG & GA & $\mathbf{A A}$ \\
\hline \multicolumn{4}{|c|}{ Family history status } \\
\hline Yes & \multirow{2}{*}{1} & \multirow{2}{*}{$0.60(1.70-0.21)$} & \multirow{2}{*}{$0.44(0.15-1.30)$} \\
\hline No & & & \\
\hline \multicolumn{4}{|l|}{ Smoking status } \\
\hline Yes & \multirow{2}{*}{1} & \multirow{2}{*}{$1.08(0.46-2.50)$} & \multirow{2}{*}{$1.3(0.59-2.90)$} \\
\hline No & & & \\
\hline \multicolumn{4}{|c|}{ Consanguinity status } \\
\hline Yes & \multirow{2}{*}{1} & \multirow{2}{*}{$0.62(0.26-1.44)$} & \multirow{2}{*}{$0.60(0.26-1.35)$} \\
\hline No & & & \\
\hline rs12430881 & $\mathbf{A A}$ & $\mathbf{A G}$ & GG \\
\hline \multicolumn{4}{|c|}{ Family history status } \\
\hline Yes & \multirow{2}{*}{1} & \multirow{2}{*}{$0.58(0.16-2.15)$} & \multirow{2}{*}{$1.80(0.65-4.98)$} \\
\hline No & & & \\
\hline \multicolumn{4}{|l|}{ Smoking status } \\
\hline Yes & \multirow{2}{*}{1} & $105(015912)$ & $108(015260)$ \\
\hline No & & $1.05(0.45-2.42)$ & $1.08(0.45-2.00)$ \\
\hline Consanguinity & & & \\
\hline Yes & 1 & $115(050-265)$ & $049(0$ 18-1 35$)$ \\
\hline No & 1 & $1.15(0.50-2.05)$ & $0.49(0.18-1.55)$ \\
\hline
\end{tabular}


Figure 1

SNP rs35958982

Well 1 indicates the DNA ladder (100bp), an amplicon (395bp) is outer band. Amplicon 272bp: allele 'A' and amplicon of $170 \mathrm{bp}$ allele ' $G$ '. 


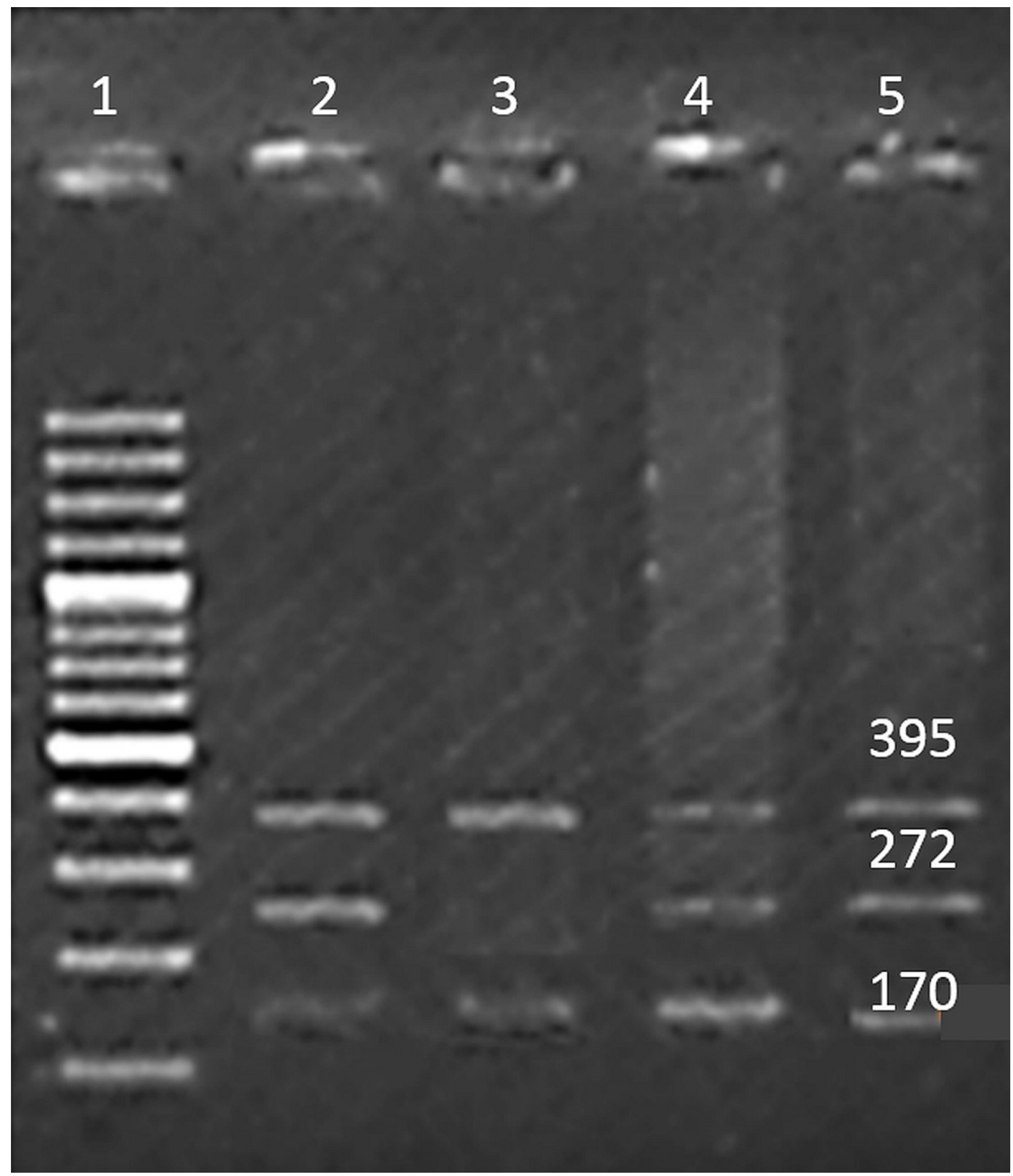


Figure 2

\section{SNP rs3780135}

Well 1 indicates the DNA ladder (50bp), an amplicon (331bp) is outer band. Amplicon 243bp:

allele 'A' and amplicon of 128bp: allele ' $G$ ' 


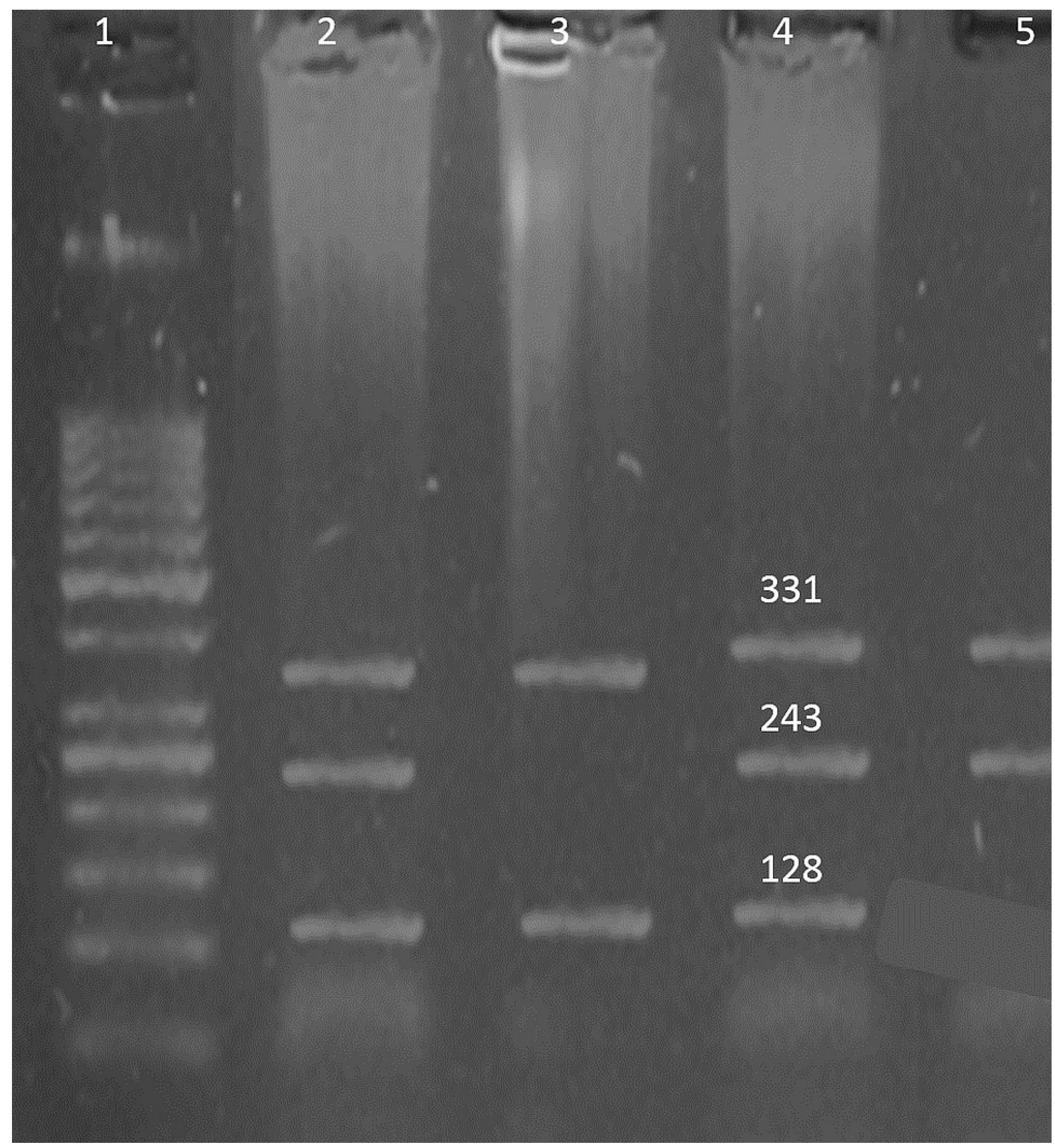


Figure 3

SNP rs12430881

Well 1 indicates the DNA ladder (100bp), an amplicon (400bp) is outer band. Amplicon 165bp: allele $\mathrm{G}$ and amplicon of $280 \mathrm{bp}$ : allele $\mathrm{A}$. 


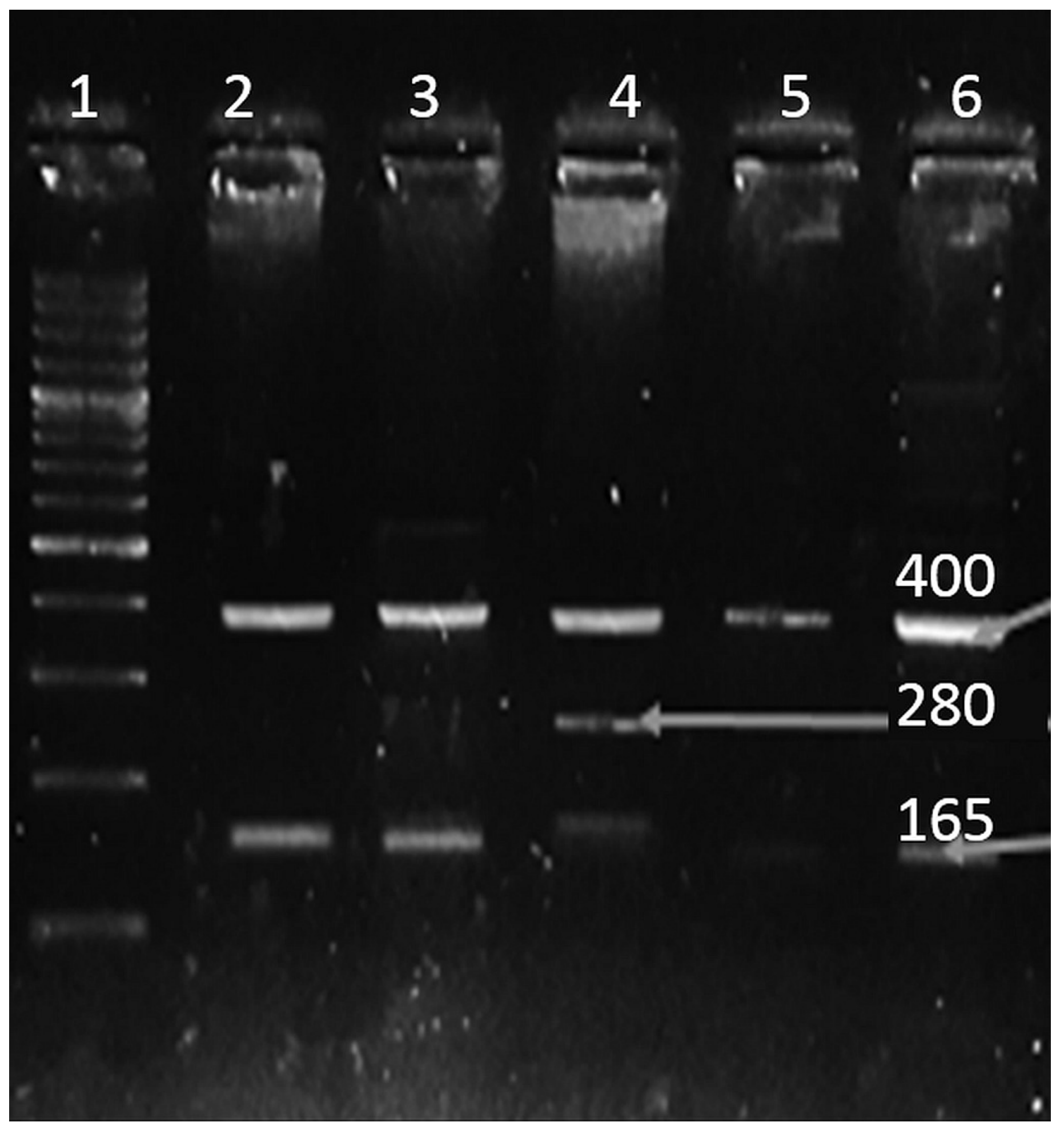

